\title{
EDITORIAL
}

\section{El corrupto duerme tranquilo}

\section{Raúl Villarroel Soto}

"El corrupto duerme tranquilo" aseguró alguna vez Susana Sierra, presidenta de la ONG Chile Transparente. Argumentaba que quien corrompe los sistemas justifica su corrupción invocando su sacrificio personal, familiar, su servicio al país y otras razones semejantes. Se ampara en redes de protección y encubrimiento a menudo integrada por familiares y también por funcionarios públicos cuya misión es precisamente la de fiscalizar, aunque no la cumplen, analistas expertos en manejos financieros y otros. Entre todos, contribuyen a la comisión de los delitos de corrupción y terminan por mermar la confianza pública, lo que inevitablemente conduce a la ciudadanía a desafectarse de sus instituciones. Por lo mismo, parece ser de importancia crucial que los servidores públicos, quienes ocupan cargos públicos para servir al Estado (autoridades, políticos, legisladores, jueces, funcionarios), orienten su comportamiento a la satisfacción de los intereses de la comunidad política antes que a los suyos propios. La reiteración de este tipo de hechos termina por hacer que las instituciones públicas tienden a ser vistas como ineficaces e ineficientes, lo que a la vez lleva a que la ciudadanía pierda la confianza en el gobierno. Por ello, cualquier mejora en la operación de los organismos públicos, apoyada con recursos, con técnicas, con innovaciones y orientada hacia una mayor responsabilidad, tendrá naturalmente mayor posibilidad de éxito, si se acompaña de principios y valores éticos.

En la reciente historia de Chile se han constituido dos comisiones presidenciales orientadas a la tarea de pensar lineamientos éticos y proponer estrategias de acción suficientemente capaces de contener un proceso de corrupción que se ha venido tornando cada vez más creciente y masivo en el país. En el año 1994, bajo el mandato del presidente Eduardo Frei Ruiz-Tagle, se constituyó la primera instancia dedicada al cumplimiento de estos objetivos. Casi 20 años después, durante el mandato de la presidenta Michelle Bachelet Jeria la segunda. No obstante, estos esfuerzos institucionales, parece que la corrupción ha entrado en nuestros días en una expansión incontenible y se ha diseminado en la actuación de múltiples actores sociales, especialmente los partidos políticos gobernantes, empresarios y operadores que se han enriquecido en dicho proceso. Sin duda alguna, un marcado relativismo ético y una real politik, han pretendido justificar a la corrupción buscando minimizarla al proponer que se trataría de un fenómeno a estas alturas normal, del cual se supone que ninguna sociedad estaría libre. Se podría hablar, entonces, de la existencia de una verdadera ideología de la corrupción, que torna aún más difícil su comprensión y por tanto su eventual reversión. 
Entonces, los problemas que a una sociedad le acarrea la omisión, el descuido, la ignorancia o el rechazo de la ética en el comportamiento de los servidores públicos y las diversas implicancias favorables que un comportamiento éticamente responsable tiene para el medio social son algunos de los asuntos problemáticos que el número IV de nuestra revista ETHIKA+, se complace en presentar ahora a sus lectores; en esta oportunidad organizado bajo el criterio editorial del Dr. Jaime Rodríguez Alba, académico de la Universidad Internacional de la Rioja (España) y la Universidad Siglo 21 (Argentina), reconocido experto en el tema de la Ética pública. Esperamos contribuir con este aporte de alcance internacional a la discusión y el análisis de tan decisivo asunto de interés común para las sociedades de nuestro tiempo.

Revista ETHIKA+ 